Seidu, R.D., Young, B.E., Thayaparan, M., Rodmell, S., Robinson, H., 2019. Mechanical and electrical (M\&E) training for quantity surveyors to contribute to carbon reduction in buildings. In: Sandanayake, Y.G., Gunatilake, S. and Waidyasekara, A. (eds). Proceedings of the $8^{\text {th }}$ World Construction Symposium, Colombo, Sri Lanka, 8-10 November 2019, pp. 453-463. DOI: doi.org/10.31705/WCS.2019.45. Available at: https://2019.ciobwcs.com/papers

\title{
MECHANICAL AND ELECTRICAL (M\&E) TRAINING FOR QUANTITY SURVEYORS TO CONTRIBUTE TO CARBON REDUCTION IN BUILDINGS
}

\author{
Rafiu Dimeji Seidu', Bert Ediale Young², Menaha Thayaparan³, Sam Rodmell ${ }^{4}$, \\ Hebert Robinson ${ }^{5}$
}

\begin{abstract}
Estimates on the level of carbon emission varies but it is generally accepted that buildings consume about half of energy and contribute to greenhouse gas emissions. Mechanical and electrical $(M \& E)$ services accounts for a significant proportion of building projects. Apart from the cost effect, a reduction in carbon footprint can be achieved through $M \& E$ services as the capital allowances system and tax relief provides the mechanism to promote sustainability through innovation in green technologies and energy efficiency. However, the training of quantity surveyors in $M \& E$ is often ad hoc making it difficult to realise the maximum potential in carbon reduction. The aim of the study is to enhance the M\&E trainings to the Quantity Surveyors (QSS) in order to better contribute to carbon reduction and sustainability of buildings. The objectives were formulated as to examine the opportunities for carbon reduction through capital allowances and tax relief and the training implications for QSs. Using an explorative survey and semi-structured interviews, the study found significant gaps in knowledge of the quantity surveyors as limited attention is given to training in $M \& E$ services. There is need for a review of training programmes to ensure that the OS professionals can maximise the potential in reducing carbon emission through the provision of appropriate cost advice on $M \& E$ services that will benefit from capital allowances and tax relief. Other countries can learn from the experience of the UK Government policy, statutory and regulatory framework that underpins the development of capital allowances and tax relief to change behaviour by providing tax and fiscal incentives that will have a positive impact on carbon reduction to mitigate climate change.
\end{abstract}

Keywords: Capital Allowances; Carbon Emission; Mechanical and Electrical (M\&E); Quantity Surveyor; Sustainability; Tax Relief.

\footnotetext{
${ }^{1}$ School of the Built Environment and Architecture, London South Bank University, UK, seidur@1sbu.ac.uk

${ }^{2}$ School of the Built Environment and Architecture, London South Bank University, UK, youngb6@1sbu.ac.uk

${ }^{3}$ Department of Building Economics, University of Moratuwa, Sri Lanka, mthayaparan@uom.lk

${ }^{4}$ Bancroft Limited, London, UK, Sam.Rodmell@bancroft.uk.com

${ }^{5}$ Head of Training Division, United Nations African Institute for Economic Development \&

Planning/Economics Commission for Africa, herbertrobinson74@ymail.com
} 


\section{INTRODUCTION}

Climate change has been an integral part of the UK government agenda since the Rio, Kyoto and Paris Summits, and it is recognised today as one of the world's most challenging issues to address (Myers, 2005). The UK government as part of its response have created the legislative framework underpinned by policies and strategies for improving the heat efficiency of buildings responsible for significant carbon emission. Estimates on the level of emission varies but it is generally accepted that buildings consume about half of energy and contribute to greenhouse gas emissions (Miller and Buys, 2008). For example, commercial property in the UK produces $10 \%$ of greenhouse gas emissions and consumes $7 \%$ of energy. It is also estimated in the UK that by 2050 about $70 \%$ of today's buildings will be standing, with $40 \%$ built before 1985 (Dixon, 2014). The UK energy policy has been redesigned recently to respond to this challenge of minimizing the impact on climate change by creating buildings with zero carbon emissions (Stevenson, 2013). In the UK, several government initiatives encouraging reform in the construction industry have been published.

Mechanical and electrical (M\&E) services are significant in construction projects in relation to the building total cost. Apart from the cost effect, issues such as energy performance, sustainability, innovation, and life cycle performance have become critical in meeting the government target of reducing carbon through decarbonisation and energy reduction in built environment. Reducing carbon footprint can also be achieved through an appropriate selection of M\&E services that will benefit from tax relief as part construction expenditure. However, the industry professionals need to be trained especially those who are responsible for giving cost or procurement advice to maximize the potential in reducing carbon emission in construction projects. The Governments policy, statutory and regulatory framework are in the form of taxation and levies, reliefs and allowances such as plant and machinery allowances, enhanced capital allowances (ECAs), subsidies and other incentives (HM Government, 2011).

Concern is often expressed regarding the challenge of meeting the requirements of clients in terms of capital expenditure (Capex) and operating expenditure (Opex) of construction projects using more sophisticated project appraisal and cost control techniques that reflects life cycle costs, cash flow and indirect costs such as taxation. However, the client's requirement must be balanced against any regulation, rules, energy sources and the liquidity of the project (HM Government, 2011). Farey (2015) argued that a longerterm approach of whole life cost will provide a more balanced picture reflecting economics, energy and carbon. The challenge for professionals in the built environment, including quantity surveyors is to find an approach where economic, social and environmental factors can be effectively captured for the clients through tax relief and capital allowances for profit maximisation. The assets that benefit from tax relief and capital allowances are mainly mechanical and electrical systems, and related systems such as cold water systems, lifts, escalators and moving walkways, external solar shading, space or water heating systems. However, limited attention is given to training of quantity surveyors in $M \& E$ services to maximize the potential in reducing carbon emission through appropriate cost advice on tax relief and capital allowances available for a range of technologies. In this context this paper addresses to examine the scope and opportunities for carbon reduction through M\&E services and to assess the implications for the training of quantity surveyors (QSs) in M\&E services. 


\section{RESEARCH METHODOLOGY}

The objectives of the study were to examine the scope and opportunities for carbon reduction through $M \& E$ services, with particular focus on capital-allowances and taxrelief, and to assess the implications for the training of quantity surveyors (QSs) in M\&E services. The objective on examining the scope and opportunities for carbon reduction through capital allowance and tax relief was achieved through a comprehensive literature review, which has been presented in the next section. In addition, data was collected on twenty-two (22) completed high rise building projects using the Building Cost Information System (BCIS) database to assess the provision of M\&E in elemental cost plans in order to highlight the significance of $\mathrm{M} \& \mathrm{E}$ in relation to the total building cost and to find out the scope for reducing the carbon foot print of a project. An exploratory survey was also conducted to establish the M\&E related factors that are significantly contributing to the quality of cost plans. As part of this survey, fifty (50) questionnaires were distributed to industry professionals such as Project Quantity Surveyor (PQS) firms/consultancies, main contractors, M\&E sub-contractors and specialist M\&E subcontractors and twenty-six (26) completed questionnaires were received, making a response rate of 52\%. Finally, three (3) in-depth qualitative expert interviews were conducted to assess the training implications for the QSs.

\section{LITERATURE REVIEW}

\subsection{SIGNIFICANCE OF M\&E SERVICES IN BUILDINGS}

The provision of mechanical and electrical (M\&E) services is a significant component of a building's overall cost, and in determining the relative success of a project (Cunningham, 2017). The more complex the building, the greater the M\&E input that will be required and often the value of M\&E can easily exceed other elements of a building project. The total cost of M\&E services has grown significantly over the last two decades due to rapidly developing technology, innovation and stringent BREEAM (Building Research Establishment Environmental Assessment Method) requirements (Li et al, 2013). For example, M\&E costs for traditional buildings has risen from 15 to $30 \%$ to between 15 to $70 \%$ of the total building costs depending on the sophistication of the services (Rawlinson and Dedman, 2010). Hence, there is a need for robust cost planning procedures at both pre and post contract stages of a project to ensure the cost of M\&E services is adequately controlled and managed as the design evolves (Swaffield and Pasquire, 2000).

After evaluating cost plans prepared by PQS on twenty-six different projects, Yusuf and Mohamed (2014) found that 97\% of cost plans were based on incomplete design information. The more uncertain the design information is at pre-contract stage, the more risk there is for the client at tender stage (Davies et al., 2009). This is further complicated by the practices of some specialist M\&E sub-contractors who hold back design ideas to gain competitive advantage during the tender, leading to difficulties in improving design solutions and providing reliable estimates (Mathew and Howell, 2005). Yusuf and Mohamed (2014) also noted that works not shown on M\&E consultant drawings were covered with provisional items including Bills of Quantities (BQ)/pricing schedules used for tendering purposes. Potts (2008) argued this approach of lump sum provision create a significant risk for the contractor for items missed by the PQS/M\&E Consultant. Odeyinka et al (2009) noted that this practice made it extremely difficult and created 
problems in determining contractors' interim valuations and pricing variations for $\mathrm{M} \& \mathrm{E}$ sub-contractors. Oforeh (2008) further noted that M\&E services were not classified properly in sections as only $10 \%$ of the cost plans reviewed made references to the appropriate location of work i.e. external, internal or roof, to allow the tenderer to make necessary allowances. Yusuf and Mohamed (2014) also cited numerous elements such as measurement of pipework and fittings including necessary accessories not clarified in the cost plans. Potts (2008) argued that this practice defeated the idea of a BQ, which is meant to provide a uniform basis for a tenderer and process of "market tests" by the PQS. For example, items such as Conduit, Trunking, Cable Tray and Cable are measured separately in the BQ but in all the cost plans they were lumped in together.

\subsection{Capital Allowances and Taxation on M\&E Services}

The capital allowances and tax relief is a specialist area within the construction industry in the UK with one of the most complex and opaque tax codes (BBC, 2010). The issue becomes complicated when working to meet the sustainability target of the government on low energy and carbon reduction. The capital allowances provide some relief on capital expenditure incurred by clients and end users as they reduce taxable profits which represent real savings. Capital allowances on M\&E services include: plant and machinery assets, fixtures and chattels, renovation of a business premises, expenditure on research and development and enterprises Zone allowances backed by the capital allowances Act 2001 and Finance Act 2008. Enhanced Capital Allowances (ECAs) was introduced in 2001 in responding to the Kyoto Agreement to reduce UK carbon emission. The assets which are considered are mainly mechanical and electrical systems, cold water systems, lifts, escalators and moving walkways, external solar shading, space or water heating systems. Such assets or systems are for improving the electrical efficiency of lighting and appliances, including the use of heating systems with renewable energy sources which can change building owners and occupiers' behaviour. In the UK, capital allowances can improve investment yield and reduce tax liability in property transactions, with the aim of achieving a significant reduction in carbon emissions through reducing demand for energy in buildings, reducing water usage, decarbonising heating and cooling supply (Robinson et al, 2015). Capital allowances are also available on expenditure incurred on refurbishment and fitting out works. Businesses are often under the misconception that becoming an environmentally responsible corporation can be costly and complicated. Nevertheless, significant savings can be achieved on energy bills through the government's Enhanced Capital Allowances (ECA) scheme (Remark Group, 2013).

Modern energy-efficient equipment can be installed into existing fittings to minimise energy bills which, coupled with the government's ECA scheme, could offer return on investment within two to three years. It is important that industry professionals such as quantity surveyors responsible for cost advice understand where saving opportunities may lie. The UK government aim to achieve 34\% reduction in carbon emissions by 2020 and half of the heat used in buildings will come from low carbon technologies by 2030 which will be backed up by government statue (HM Government, 2011). As part of the government's climate change management programme, the Enhanced Capital Allowances (ECA) provides 100 per cent first year capital allowance for businesses investing in energy-saving equipment. Companies can apply for assistance with upgrades through the ECA scheme, with the tax relief also extending to parts and labour. As of 1st December 2012, there were 15,968 energy-efficient products eligible for 100 per cent tax relief (Remark Group, 2013). Eligibility is determined from the Energy Technology List 
(ETL) which is typically product specific to review whether they will benefit from ECA (Farey, 2015). For residential or certain charitable developments, consideration is on energy-saving materials subject to a reduced rate of VAT. A variety of tools are available to assess carbon emission such as the Carbon Calculator (Faithful + Gould, 2012). Technologies contribute to carbon reduction on variety of M\&E services. Some examples are; a high efficiency boilers increase capital cost (Capex) by $£ 9,000\left(£ 1 / \mathrm{m}^{2}\right)$, reduce annual running cost (opex) by $£ 15,000$ but significantly reduce carbon emissions $(35,000$ $\mathrm{kg} \mathrm{CO} 2$ per annum or $4 \mathrm{~kg} \mathrm{CO} / \mathrm{m}^{2}$ ); geothermal and heat pumps increase capital cost (capex) by $£ 55,000\left(£ 6.5 / \mathrm{m}^{2}\right)$, decrease annual running cost (opex) by $£ 6,000$ with significant reduction in annual carbon emission by $28,000 \mathrm{~kg} \mathrm{CO}\left(3.5 \mathrm{~kg} \mathrm{CO} / \mathrm{m}^{2}\right)$; high efficiency lighting controls initially increase capital cost (capex) by $£ 230,000\left(£ 27 / \mathrm{m}^{2}\right)$, decrease annual running cost (opex) by $£ 4,000$ with significant reduction in annual carbon emission by $12,000 \mathrm{~kg}\left(1.5 \mathrm{~kg} \mathrm{CO} / \mathrm{m}^{2}\right)$; and Photovoltaics (PV) increase capital cost (capex) by $£ 510,000\left(£ 60 / \mathrm{m}^{2}\right)$, decrease annual running cost (opex) by $£ 11,000$ with significant reduction of carbon by $61,000 \mathrm{~kg} \mathrm{CO}_{2}\left(7.5 \mathrm{~kg} \mathrm{CO}_{2} / \mathrm{m}^{2}\right)$ (Lockie, 2015).

\subsection{SKILls of Professional QUANTITY SURVEYoR's (PQS)}

Due to the rising and significant proportion of building cost that is represented by $M \& E$ services, the demand for measurement skills required to produce bills of quantities (BQ) for M\&E services is increasing (McCaffrey, 2010). However, PQS's and main contractor QS's do not have the required skills and knowledge to provide adequate cost advice for M\&E services (Olanrewaju and Anahve, 2015). Ashworth et al., (2013) found that most PQS firms consider M\&E services as the responsibility of a specialist. Some PQS firms only provide mainstream QS services that are focused on the entire project including all specialist work packages. However, certain consultancies employ dedicated M\&E specialist QSs to manage the M\&E section of all projects.

Earlier studies by Swaffield and Pasquire (2000) noted that there were problems with the knowledge base and skills of quantity surveyors relating to the technologies associated with M\&E services. Most recently, Mitchell (2016) identified the main barrier as the lack of technical knowledge of the PQS in the development of fully measured mechanical and electrical BQ. Mitchell (2016) also noted that M\&E sub-contractors had inadequate experience with items measured in BQ by the PQS. Cunningham (2017) argued that incomplete designs and lack of M\&E knowledge by PQS's has contributed to the absence of detailed measurement of M\&E services in the production of bills of quantities. Mitchell (2016) noted that PQS consultancies were still best placed to control project costing but there is a need for upskilling on the technology side. It is widely acknowledged that main contractors' QS also lack M\&E knowledge but their interaction with the M\&E subcontractors' QSs provide strong channels for knowledge transfer and support upstream (Olanrewaju and Anahve, 2015). Though QSs have a better understanding of M\&E services compared to twenty years ago (Cartlidge, 2011), clients are increasingly frustrated with the inability of PQS's to provide accurate cost advice in their cost plans for M\&E services as using lump sum approaches to price M\&E services is inadequate (Olanrewaju and Anahve, 2015). It was further noted by Olanrewaju and Anahve (2015) that despite the existence of limited specialist degree programmes in place at UK universities, there are still question marks with regard to the quality and content of the programmes in terms of the required knowledge expected of M\&E quantity surveyors including measurement skills in M\&E works. Ashworth et al. (2013) argued that Quantity 
Surveyors, who do not possess the required competencies, could not provide value added service for the Client, design team or their employer.

\section{FINDINGS AND DISCUSSIONS}

\subsection{COST OF M\&E SERVICES IN BUILding ProJeCtS}

M\&E services are categorised in the Building Cost Information Service (BCIS) database into various sub-elements. For example, 5F (Space Heating and Air Conditioning), 5H (Electrical Installations), 5K (Fire and Lightning Protection) or 5L (Communications and Security Installations). Investing in carbon efficient M\&E services can significantly reduce the demand for energy and carbon footprint. Prevention is better than cure as money spent putting measures in place at the initial stage of a project by exploring the provision for enhanced capital allowances systems in meeting the government target can reduce the carbon footprint of a building over its life cycle and promote sustainable homes. Based on 22 projects analysed (See Table 1) from the BCIS database, the cost for M\&E provision is significant in building projects.

Table 1: Analysis of $M \&$ E provision in projects

\begin{tabular}{|c|c|c|c|c|c|c|c|}
\hline & Description and type & $\begin{array}{l}\text { No of } \\
\text { Storey }\end{array}$ & $\begin{array}{l}\text { Building } \\
\text { Cost (£) }\end{array}$ & $\begin{array}{l}\text { Floor area } \\
\left(\mathbf{m}^{2}\right)\end{array}$ & $\begin{array}{l}\text { M\&E Cost } \\
\text { (£) }\end{array}$ & $\begin{array}{l}\text { M\&E as \% } \\
\text { of Building } \\
\text { Cost }\end{array}$ & $\begin{array}{l}\text { M\&E } \\
\text { Cost } \\
\left(\mathfrak{f} / \mathbf{m}^{2}\right)\end{array}$ \\
\hline 1 & New 45 Flats & 6 & $£ 6,303,654$ & $3,863 \mathrm{~m}^{2}$ & $£ 1,494,452$ & 24 & $£ 387$ \\
\hline 2 & New 11 Apartments & 6 & $£ 1,274,196$ & $845 \mathrm{~m}^{2}$ & $\begin{array}{l}£ 190,880 \\
\text { Not explicit }\end{array}$ & 15 & $£ 226$ \\
\hline 3 & $\begin{array}{l}\text { New } 136 \text { Flats and } 13 \\
\text { Houses }\end{array}$ & 7 & $£ 17,154,111$ & $14,799 \mathrm{~m}^{2}$ & $£ 4,763,970$ & 28 & $£ 322$ \\
\hline 4 & New 66 Apartments & 6 & $£ 7,732,617$ & $7,367 \mathrm{~m}^{2}$ & $£ 2,002,416$ & 26 & $£ 272$ \\
\hline 5 & New 188 Flats & 10 & $£ 26,909,535$ & $20,439 \mathrm{~m}^{2}$ & $£ 5,871,855$ & 22 & $£ 287$ \\
\hline 6 & $\begin{array}{l}\text { Refurbishment of } 9 \\
\text { Luxury Flats }\end{array}$ & 6 & $£ 3,366,871$ & $1,081 \mathrm{~m}^{2}$ & $£ 891,232$ & 27 & $£ 824$ \\
\hline 7 & New 17 Flats & 6 & $£ 1,370,581$ & $1,461 \mathrm{~m}^{2}$ & $\begin{array}{l}£ 333,055 \\
\text { Not explicit }\end{array}$ & 24 & $£ 228$ \\
\hline 8 & New 60 Flats & 7 & $£ 6,877,891$ & $5,798 \mathrm{~m}^{2}$ & $\begin{array}{l}£ 1,506,881 \\
\text { Not explicit }\end{array}$ & 22 & $£ 260$ \\
\hline 9 & New 29 Flats & 7 & $£ 2,817,140$ & $2,161 \mathrm{~m}^{2}$ & $£ 837,498$ & 30 & $£ 388$ \\
\hline 10 & New 27 Flats & 7 & $£ 2,916,416$ & $2,343 \mathrm{~m}^{2}$ & $£ 590,868$ & 20 & $£ 252$ \\
\hline 11 & New 67 Flats & 7 & $£ 8,067,258$ & $5,995 \mathrm{~m}^{2}$ & $\begin{array}{l}£ 2,286,888 \\
\text { Not explicit }\end{array}$ & 28 & $£ 381$ \\
\hline 12 & $\begin{array}{l}\text { Conversion of Offices } \\
\text { to Flats }\end{array}$ & 6 & $£ 2,984,391$ & $1,078 \mathrm{~m}^{2}$ & $\begin{array}{l}£ 1,067,266 \\
\text { Not explicit }\end{array}$ & 36 & $£ 990$ \\
\hline 13 & New Flats & 6 & $£ 4,296,806$ & $3,856 \mathrm{~m}^{2}$ & $\begin{array}{l}£ 1,132,466 \\
\text { Not explicit }\end{array}$ & 26 & $£ 294$ \\
\hline 14 & Apartments & 8 & $£ 2,667,871$ & $2,695 \mathrm{~m}^{2}$ & $\begin{array}{l}£ 641,340 \\
\text { Not explicit }\end{array}$ & 24 & $£ 238$ \\
\hline
\end{tabular}




\begin{tabular}{|c|c|c|c|c|c|c|c|}
\hline & Description and type & $\begin{array}{l}\text { No of } \\
\text { Storey }\end{array}$ & $\begin{array}{l}\text { Building } \\
\text { Cost (f) }\end{array}$ & $\begin{array}{l}\text { Floor area } \\
\left(\mathbf{m}^{2}\right)\end{array}$ & $\begin{array}{l}\text { M\&E Cost } \\
\text { (£) }\end{array}$ & $\begin{array}{l}\text { M\&E as \% } \\
\text { of Building } \\
\text { Cost }\end{array}$ & $\begin{array}{l}\text { M\&E } \\
\text { Cost } \\
\left(\mathfrak{f} / \mathbf{m}^{2}\right)\end{array}$ \\
\hline$\overline{15}$ & New 12 Flats & 6 & $£ 1,058,579$ & $963 \mathrm{~m}^{2}$ & $\begin{array}{l}£ 176,992 \text { Not } \\
\text { explicit }\end{array}$ & 17 & $£ 184$ \\
\hline 16 & New Houses and Flats & 7 & $£ 8,314,764$ & $9,229 \mathrm{~m}^{2}$ & $\begin{array}{l}£ 176,992 \\
\text { Not explicit }\end{array}$ & 2 & $£ 184$ \\
\hline 17 & New Apartment Block & 10 & $£ 22,462,729$ & $9,633 \mathrm{~m}^{2}$ & $£ 7,871,300$ & 35 & $£ 817$ \\
\hline 18 & $\begin{array}{l}\text { New Holiday } \\
\text { Apartments }\end{array}$ & 6 & $£ 3,049,550$ & $1,832 \mathrm{~m}^{2}$ & $£ 722,866$ & 24 & $£ 395$ \\
\hline 19 & Fitting Out of Flats & 6 & $£ 947,798$ & $1,851 \mathrm{~m}^{2}$ & $£ 191,555$ & 20 & $£ 103$ \\
\hline 20 & $\begin{array}{l}\text { New General and } \\
\text { Wheelchair Flats }\end{array}$ & 7 & $£ 2,508,756$ & $2,157 \mathrm{~m}^{2}$ & $\begin{array}{l}£ 710,013 \\
\text { Not explicit }\end{array}$ & 28 & $£ 329$ \\
\hline 21 & New Apartment Block & 10 & $£ 8,723,304$ & $6,202 \mathrm{~m}^{2}$ & $£ 2,249,844$ & 26 & $£ 363$ \\
\hline 22 & $\begin{array}{l}\text { Conversion of Office } \\
\text { Block to Flats }\end{array}$ & 9 & $£ 1,398,015$ & $999 m^{2}$ & $£ 523,796$ & 38 & $£ 524$ \\
\hline
\end{tabular}

Table 1 shows that the cost of M\&E provision is significant in most of the projects with M\&E cost of 19 out of 22 projects of at least $20 \%$ of the total building cost. In over 10 projects, the $M \& E$ cost in relation to total building cost exceeded $25 \%$. In 8 projects, the $\mathrm{M} \& \mathrm{E}$ cost is $20-24 \%$ of the total building cost. However, a common barrier to the realising the potential to reducing carbon is the lack of an explicit approach to costing specific items for M\&E provision in the cost plan. There is an over reliance on ad hoc approaches with limited specification that affects the accuracy of costing for M\&E as well as the potential to explore sustainable technologies to reduce carbon. The findings suggest there is a need for adequate specification for $\mathrm{M} \& \mathrm{E}$ in the cost plan in order to strengthen the link between M\&E services and carbon reduction through the enhanced capital allowances system and tax relief.

\subsection{Reasons for Poor Quality in M\&E Cost Advice and Cost Plan}

Of the 50 questionnaires sent out 26 were completed and analysed. Most of the respondents $(91 \%)$ were quantity surveyors with $83 \%$ having more than five years work experience in the construction industry, where $63 \%$ were at senior management level. About two-thirds surveyed $(62.5 \%)$ were M\&E specialists. The purpose of this survey was to explore the factors contributing to the improved quality of cost plan. It is vital that the QSs should be able to ascertain the costs associated with M\&E services clearly in order to find out how and where the carbon reduction can be achieved. Based on Table 1, it is clearly evident that in almost half of the projects the M\&E provisions are not clearly accounted or specified. Hence, the questionnaire survey identified the main causes for this lack of quality of M\&E services in cost plans. The two major causes identified through the questionnaire are lack of consultant's contributions at the design stage and lack of experience or trainings on M\&E services for the QSs. Half of the respondents believe the quality of initial M\&E design information at RIBA (Royal Institute of British Architect) stages 1 and 2 significantly impact on the quality of cost plan. Further, effective communication and level of input by the M\&E Consultant at the design stage were significant factors that affect the quality and accuracy of the pre-tender cost plan. It was revealed that due to the significance of $\mathrm{M} \& \mathrm{E}$ costs, the clients expect to receive a better 
cost advice and cost plan that clearly identifies the M\&E cost components. However, that aspect is still lacking among the QSs, as the M\&E costs are mostly not quantified. 50\% of the respondents received some training to put together an M\&E cost plan and believed that the degree or short-term courses undertaken helped in their role. Over half (54\%) of participants believed that gaining site experience in installing M\&E services, either during graduate training or while working, would improve their ability to understand M\&E services. As such, for QSs to produce good cost advice and cost plan on M\&E services, improving their knowledge and experience in that filed is vital.

\subsection{TRAINING OF QUANTITY SURVEYORS}

Expert interviews were conducted to assess the implications of M\&E related training for QSs. The findings are discussed below.

\subsubsection{Demand for M\&E Quantity Surveyors}

All three experts interviewed agreed that more M\&E QS specialists need to be employed within their organisations as there is currently a small pool of specialist in the industry. As a result, a significant number of projects do not have a specialist M\&E QS involved leading to costs that is often inaccurate and unrealistic during cost planning. On smaller projects (post contract), the experts noted that M\&E involvement may be limited and more often the M\&E services are provided on an ad-hoc basis dealing with specific areas such as on variations etc. One of the experts noted the following:

"It is a risk that even on smaller projects if there is no M\&E PQS then there could be risks with over-inflated valuations which could mask other more serious issues (such as cash flows) and over exaggerated variation claims".

Expert B agreed that M\&E specialists should have more involvement in the pre-tender costing process and the view of Expert $\mathrm{C}$ is that the variation agreements can be hindered by the non-involvement of M\&E surveyors. The experts explained that in general PQS's will lean on the Consultant for technical input, however changes related to design issues will be defended by the Consultant naturally and this will slow down the process of agreeing a change and the costs associated with it. Expert A agreed with this ideology and used the phrase "contractor opportunity", as they often expose the contractors over inflation.

\subsubsection{Need for M\&E Specialist Training}

All the experts agreed that there is need for significant improvement in the methods and practices used to provide $M \& E$ cost advice to improve the certainty of cost advice at pretender stage. Expert A referred to the fact that the industry is constantly evolving, and methods and practices need to be kept up to date. Expert B argued that their needs to be an increase in the number of M\&E QS's in the industry and better liaison with the design team:

"I think the key to improving $M \& E$ cost advice is to increase the number of dedicated $M \& E$ QS's in the industry and this could be achieved through apprenticeships which will help improve and develop the technical knowledge earlier on. I also feel that on larger projects there can often be a discord within the project team, i.e. a lack of communication between the design team and the cost team which can often create an air of resentment and be a strain on team morale." 
All three experts explained that their undergraduate degree qualifications had no relevance to $\mathrm{M} \& \mathrm{E}$ services as the content of their programmes and the curriculum specifications did not reflect what is actually required to carry out work in designing, measuring and installing M\&E services. However, training programme for Expert B included a sandwich year, which helped him prepare for work in industry. The Experts advised that anyone interested in taking up a career in M\&E quantity surveying should obtain a job role first and undertake a degree programme through their respective companies, so they can "learn- on- the-job" and get a blend of experience from practice and the academic environment.

\subsubsection{Developing Appropriate M\&E Training Programmes for Industry}

Most of the PQS completed general quantity surveying programmes instead of specialised training on M\&E due to a shortage of university offering the programme with the appropriate curriculum content. There is only one university that is offering the course, but this is not accessible to students who aspire to become M\&E quantity surveyors. The University of Salford offer postgraduate degree programme (PgDip/MSc Mechanical \& Electrical Quantity Surveying), with the aim of "creating reflective practitioners in quantity surveying who have a knowledge and understanding of procurement and financial management and recognise the significance of process, technology and people to the success of mechanical and electrical projects". The general degree course has helped PQS to undertake their role with the expectation that sufficient level of M\&E onthe-job technical training will be provided. Specialist M\&E QS's working for subcontractors tend to benefit from on-the-job training due to significant site exposure but this needs to be addressed throughout the supply chain. Graduate and trainee surveyors as part of their training, should be spending a period on site, whether as a block period or intermittently. The exposure to installing $M \& E$ services on site can benefit quantity surveyors.

\section{CONCLUSIONS}

The study has examined the potential for reducing carbon emission through the system of capital allowances and tax relief and the implications for the training of QSs in M\&E. In order to achieve carbon reduction, it is vital to understand the M\&E services associated with a building at the initial stage. But it was evident that in almost half of the building cost plans analysed, there were no clear determination of ME services. A key barrier in reducing carbon in buildings is therefore, the lack of clear determination of M\&E services in the cost plans. One contributing factor for this is the lack of technical knowledge of QS's in M\&E. Another contributing factor is the ineffective communication with the design team for technical inputs on range of technological options that will attract capital allowances and tax relief and at the same time reduce the carbon footprint. There is a need for the introduction of M\&E training programmes to improve the knowledge of QSs in providing M\&E cost advice that will help in reducing the carbon footprint of buildings. Colleges, universities, companies and professional organisations including the RICS, $\mathrm{CIOB}$ and AMP should be providing and/or supporting through accreditation and sponsorship of M\&E training programmes (such as internships, thin and thick sandwich placements, guest lectures) at both undergraduate and postgraduate levels. Through the introduction of appropriate curriculum content in terms of breadth and depth in core building services modules/credits the opportunities in carbon reduction can be achieved using fiscal and tax incentives for sustainable development. Training will ensure more 
clarity and confidence in dealing with M\&E design options and UK complicated tax system so that clients can benefit from tax relief and allowance which will result in achieving the UK Government carbon reduction target in delivering sustainable homes. Other countries can learn from the experience of the UK changing behaviour through tax and fiscal incentives that will have a positive impact on carbon reduction to mitigate climate change.

\section{REFERENCES}

Ashworth, A.K., Hogg, C. and Higgs, C., 2013. Will's Practice and Procedure for the Quantity Surveyors. $13^{\text {th }}$ ed. UK: John Wiley and Sons Ltd.

BBC, 2010. Tax system to be simplified to encourage investment [online]. Available from: http://www.bbc.co.uk/news/uk-politics [Accessed 14 March 2019].

Cartlidge, D., 2011. New Aspect of Quantity Surveying Practice. UK: Butterworth - Heinemann.

Cunningham, T., 2017. What Causes Cost Overruns on Building Projects? - An Overview. School of Surveying and Construction Management, Dublin Institute of Technology, Dublin.

Davis, P.R., Love, P.E. and Baccarini, D., 2009. Bills of Quantities: nemesis or nirvana?. Structural Survey, 27(2), pp.99-108.

Dixon, T., 2014. What does "retrofit" mean, and how can we scale up action in the UK sector?. Journal of Property Investment and Finance, 32(4), pp.443-452.

Faithful+Gould, 2012. Construction Carbon Calculator [online]. Available from: http://www.fgould.com/carbon_calculator [Accessed 2 February 2012].

Farey, P., 2015. Carbon Reduction and Fiscal Incentives for Sustainable Design. Design Economics for the Built Environment: Impact of Sustainability on Project Evaluation, pp.152-176.

HM Government, 2011. The Carbon Plan: Delivering our Low Carbon Future [online]. HM Government. Available from: http://www.hmrc.gov.uk [Accessed 10 March 2019].

HMRC, 2016. HM Revenue and Customs [online]. Available from: http://www.hmrc.gov.uk [Accessed 15, March 2019].

Li, Q., Syal, M. Turner, N. and Arif, M., 2013.Constructors and Innovation Credits in Green Building Projects. Construction Innovation, 13, pp.320-338.

Lockie, S., 2015. Life Cycle Costing and Sustainability Assessments: An Industry Perspective with Case Studies. Design Economics for the Built Environment: Impact of Sustainability on Project Evaluation, pp.262-283.

Matthews, O. and Howell, G.A., 2005. Integrated project delivery an example of relational contracting. Lean construction journal, 2(1), pp.46-61.

McCaffrey, J., 2010. What is an M\&E QS?. Royal Institution of Chattered Surveyors Students Construction Journal, pp22-23.

Miller, E. and Buys, L., 2008. Retrofitting commercial office buildings for sustainability: tenants' perspective. Journal of Property Investment and Finance, 26(6), pp.552-561.

Mitchell, C., 2016. A Time for Change - An Evaluation of the Ability of the Quantity Surveyor to Measure Mechanical and Electrical Services Under the Irish Public Works Contracts (designed by the employer) using the Agreed Rules of Measurement [online]. Other Resources. Paper 61. Available from: https://arrow.dit.ie/beschreoth/61 [Accessed 23 January 2019]

Myers, D., 2005. A review of construction companies' attitudes to sustainability. Construction Management and Economics, 23(8), pp.781-785.

Odeyinka, H.A., Kelly, S., and Perera, S., 2009. An Evaluation of the Budgetary Reliability of Bills of Quantities in Building Procurement. The Construction and Building Research Conference of the Royal Institution of Chartered Surveyors, 11 September 2009, University of Cape Town. pp.435-446.

Oforeh, E., 2008. Installation and Electrical Works in Buildings. $2^{\text {nd }}$ ed., Lagos: Cosines.

Olanrewaju, A. and Anahve, P.J., 2015. Duties and responsibilities of quantity surveyors in the procurement of building services engineering. Procedia Engineering, 123, pp.352-360. 
Potts, K., 2008. Change in the quantity surveying profession. Collaborative Relationships in Construction. UK: Wiley, pp.42-58.

Rawlinson., S., and Dedman, D., 2010. Specialist Costs: M\&E Services [online]. Davis Langdon Building Magazine. Available from: www.building.co.uk/specialist-costs-me-services/5001903.article [Accessed 15 May 2017]

Remark Group, 2013. Government Enhanced Capital Allowance scheme befits energy-efficient businesses, reminds the Remark Group. Business Wire (English) Regional Business News.

Robinson, H., Symonds, B., Gilbertson, B. and Ilozor, B. eds., 2015. Design Economics for the Built Environment: Impact of Sustainability on Project Evaluation. John Wiley \& Sons.

Stevenson, F., 2013. Reducing energy demand through retrofitting buildings. Building Research and Information, 41(5), pp.605-608.

Swaffield, L.M. and Pasquire, C.L., 2000. Improving early cost advice for mechanical and electrical services by considering functions and client/design team communication. Journal of Financial Management in Construction and Property, 5(12), pp.3-13.

University of Salford, [online]. Available from http:// www.salford.ac.uk/pgt-courses/quantity-surveyingmechanical-and-electrical [Accessed 12 December 2016]

Yusuf, G.A. and Mohamed, S.F., 2014. Perceived benefits of adopting Standard-Based pricing mechanism for mechanical and electrical services installations. Construction Economics and Building, 14(2), pp.104-119. 